\title{
The Business Performance of Culinary Sector: A Study of SMEs Sector in Bali
}

Submitted 13/05/20, $1^{\text {st }}$ revision 14/06//20, $2^{\text {nd }}$ revision $28 / 08 / 20$, accepted $10 / 09 / 20$

\author{
N.N. Kerti Yasa ${ }^{1}$, G.N. A.J. Widagda ${ }^{2}$, D. Asih ${ }^{3}$, N.L. Wayan Sayang \\ Telagawathi ${ }^{4}$, G.A. Ketut Giantari ${ }^{5}$, Made Setini ${ }^{6}$, Endi Rekarti ${ }^{7}$
}

\begin{abstract}
:
Purpose: The study aims to explain the role of business innovation strategies mediating the effect of entrepreneurial orientation on the performance of SMEs.

Approach/Methodology/Design: The method of determining the sample used is purposive sampling, the culinary sector SMEs in Denpasar City. The sample used was 120 culinary SMEs represented by the owner/manager as respondents. Data collection is done by distributing questionnaires offline and online using Google forms that have been tested for validity and reliability. The data analysis technique used is the SEM-PLS Analysis.

Findings: The results showed that the entrepreneurial orientation variable positively and significantly affects business performance. Entrepreneurial orientation has a positive and significant effect on business innovation strategies, and business innovation strategies also have a positive and significant effect on business performance.

Practical Implications: Therefore, the culinary sector SMEs in the Denpasar city must always improve its entrepreneurial orientation culture, especially in the courage to bear the risk, increase innovation in distribution innovation to customers be able to improve their business's performance achievements.

Originality/Value: The business innovation strategy can significantly mediate the effect of entrepreneurial orientation on the culinary sector SMEs' business performance.
\end{abstract}

Keywords: Entrepreneurial orientation, business innovation strategy, business performance, SMEs, culinary sector.

JEL classification: G15, G32.

Paper Type: Literature review study.

${ }^{1}$ manraikerti@yahoo.co.id;

2 agungwidagda@gmail.com;

3 daru.asih1303@gmail.com;

${ }^{4}$ gemilangsuryawan@gmail.com;

5 ayugiantari@gmail.com;

${ }^{6}$ Gitan4nd4@gmail.com; 


\section{Introduction}

The development of Small and Medium Enterprises (SMEs) is quite rapid in Indonesia, especially those that sell food and beverages. SMEs that sell food and beverages are included in the culinary sector SMEs. Culinary sector SMEs always survive in various economic conditions because the products sold are products that meet the basic needs of consumers. Likewise, at present, in the Covid-19 pandemic, the number of culinary sector SMEs has increased because workers who used to work in the tourism sector switched from employees to culinary business people.

Therefore, the development of the culinary sector SMEs are always growing, which has led to increasingly fierce competition conditions. The increasingly fierce competition certainly has an impact on the achievement of these SMEs. According to the results of an initial survey by conducting interviews with 15 people in the Culinary sector SMEs in Denpasar Bali, Indonesia, information was obtained that their performance had decreased their sales turnover by an average of around 15 percent in the past year. Seeing the existing phenomena, it is necessary to think about the factors that need to be done so that the culinary sector SMEs' performance can survive and can increase. One of them is to develop creative and innovative behavior. Creative and innovative behavior is an indicator of entrepreneurial orientation variables. Therefore, to maintain and improve its performance, SMEs in the culinary sector must always develop their entrepreneurial orientation.

Various studies in entrepreneurship explain the important entre perineurial orientation and its impact on business performance (Schever et al., 2014; Pratono and Mahmood, 2015; Alvare-Torres et al., 2019). Entrepreneurial orientation is seen by the behavior of business people who are always innovative, proactive, dare to be independent, dare to compete, and dare to bear risks and business performance achieved in terms of sales volume growth, market position, and market growth (Setini et al., 2020). Gupta and Gupta (2015) have examined the impact of entrepreneurial orientation on business growth as measured by sales growth and profit growth, but research from Arshad et al. (2014) showed no significant entrepreneurial orientation effect on company performance.

The existence of this research gap needs to be added with mediating variables. Variables that are suitable to mediate entrepreneurial orientation towards SME's performance are business innovation strategy variables. This is because if the entrepreneurial orientation changes, the business strategy that is implemented also changes and by existing environmental conditions, and of course, changes in business strategy impact improving performance (Corallo et al., 2018). Based on the existing phenomena, this study will examine the effect of entrepreneurial orientation on business innovation strategies and their impact on culinary SMEs' performance in the City of Denpasar Bali, Indonesia. 


\section{Literature Review, Conceptual Framework, and Hypotheses}

\subsection{Entrepreneurial Orientation}

Entrepreneurial orientation is understood as the process of making corporate strategy, structure, and behavior characterized by innovation, proactivity, risktaking, competitive aggressiveness, and autonomy, facilitating the search for opportunities (Anderson et al., 2015). Also, Alvare-Torres et al. (2019) state that entrepreneurial orientation can be determined based on proactive, innovative, and risk-seeking behavior. In another section, researchers Tseng and Tseng (2019) stated that there are five indicators of corporate entrepreneurship that affect company performance, namely: autonomy; innovativeness, risk-taking; proactiveness; competitive aggressiveness. Entrepreneurial companies that want to improve their position need to surpass competitors (Hutahayan, 2019). Autonomy is positively associated with the emergence of entrepreneurial activities, creating an entrepreneurial environment, and looking for opportunities and exploitative behavior (Schepers et al., 2014; Arshad et al., 2014).

\subsection{Business Innovation Strategy}

Organizations must develop and adapt acceptable alignments to their environment to survive and thrive in highly competitive markets (Anwar and Hasnu, 2016). Business innovation strategy refers to the ability of entrepreneurs or companies related to the analysis of the company's external and internal environment, formulation of strategies, implementation of plans designed to achieve goals, and evaluation to get feedback in formulating the future of the strategy (Setini et al., 2020; Yasa et al., 2016; Hutahayan, 2019). Also, contingency theory states that a company's success depends on how it can relate to situational factors such as the environment (Bahadir et al., 2015). The study shows that Porter's three generic strategies are relevant for large companies and SMEs.

According to Anwar and Hasnu (2016), small companies with high strategic flexibility index generally perform better in fierce competition than companies with low strategy flexibility. Culinary sector SMEs in the COVID - 19 pandemic periods is certainly demanded also to have a business strategy with high strategy flexibility. One of the high flexibility strategies is to make various innovations in running a business in this study using research indicators referring to various innovations carried out, including product innovation, service innovation, promotional innovation, and distribution innovation.

\subsection{Business Performance}

Performance is the result of a business that has been done by entrepreneurs in the past and is used as a measure of work performance by using certain valuation methods (Alvares-Torres et al., 2019). Performance can also be interpreted as an 
achievement that can be achieved by an organization in a certain period. Business performance is generally measured using indicators of financial performance and market performance. In this study using business performance indicators, there are sales volume growth, market position, and market growth (Hutahayan, 2019).

\subsection{Research Conceptual Framework}

Entrepreneurial orientation can influence a company's business performance (Arshad et al., 2014). This is supported by several studies, such as the same study conducted by Gupta and Gupta (2015), Tseng and Tseng (2019). The study shows a significant positive relationship between entrepreneurial orientation on business performance. The same result is also supported by research conducted by Hutahayan (2019). In addition to entrepreneurial orientation, business performance is largely determined by the business strategy implemented. Business strategy is an important factor in a company's performance due to the evolution of the competitive environment. Several studies show the effect of entrepreneurial orientation on business strategies, including Pratono and Mahmood (2015), and Corallo et al. (2018).

Furthermore, business strategies determine the achievement of business performance. If the business strategy that is implemented is suitable for the existing situation and conditions, then the business performance will increase (Anwar and Hasnu, 2016). Strategy innovative business will be able to create a new system that is unique and accepted by consumers and will increase the success of SME entrepreneurs (Putra et al., 2020)

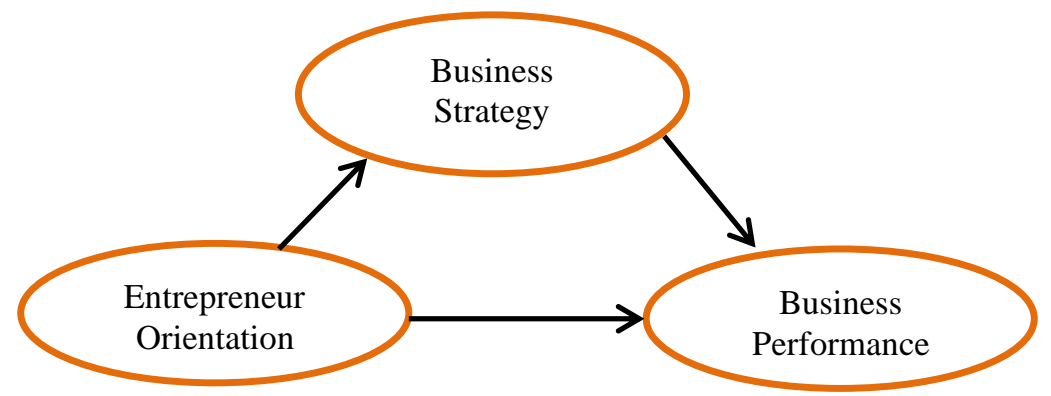

Figure 1. Research Conceptual Framework

Source: Authors.

\subsection{Research Hypothesis}

Based on the existing conceptual framework, the research hypotheses that can be compiled are as follows:

H1 : Entrepreneurial orientation has a positive and significant effect on business performance 
H2 : Entrepreneurial orientation has a positive and significant effect on business strategy.

H3 : Business strategy has a positive and significant effect on business performance.

\section{Research Methodology}

When viewed from the research purposes, this research is a type of causality research. This study aims to examine the causality relationship between the variables of entrepreneurial orientation, business strategy, and business performance. This research was conducted in the culinary sector SMEs in the city of Denpasar. The subjects in this study were the culinary sector SMEs. The object in this study is a business-performance that is influenced by entrepreneurial orientation and business strategy.

In this study, three types of variable data are examined: independent variables: entrepreneurial orientation (X) adoption indicator (Tseng and Tseng, 2009), autonomy, innovativeness, proactiveness, competitive aggressiveness. Mediating variables: business innovation strategy (Y1) adoption indicator (Yasa et al., 2016; 2020; Setini et al., 2020) product, service, promotion, distribution. Dependent variable: business performance (Y2) adoption from Hutahayan (2019) with indicator sales volume, market share, market growth. The research population is the entire culinary sector SMEs in the city of Denpasar Bali, Indonesia, with a sample size of this study 120 culinary SMEs. Indicator variables measured using a five-level Likert scale 1-5 (disagree until strongly agree). The instruments used were tested for validity and reliability to measure what they wanted to measure and to know the respondents' consistency of responses. Testing the instrument's validity using the Pearson product moment correlation technique with a minimum limit of $\mathrm{r}=0.3$. Instrument reliability testing is done by calculating the reliability coefficient of Cronbach's Alpha with a minimum limit of Alpha coefficients > 0.6. Both tests use the SPSS computer program. This analysis is used to describe the research variables without generalizations. The data collected was then tabulated in a table and discussed descriptively. The data analysis technique used in this study is the SEMPLS Analysis technique.

\section{Results and Discussion}

After conducting the research, the results can be presented as follows. The characteristics of respondents, according to demographic characteristics, are presented in Table 2. 
Table 2. Characteristics of Respondents

\begin{tabular}{|c|c|c|c|c|}
\hline No & Variable & Classification & $\begin{array}{l}\text { Number of } \\
\text { people }\end{array}$ & Percentage \\
\hline \multirow{2}{*}{1} & \multirow{2}{*}{ Gender } & Male & 55 & 45,83 \\
\hline & & Female & 65 & 54,17 \\
\hline Total & & & 120 & 100,00 \\
\hline \multirow{4}{*}{2} & \multirow{4}{*}{ Age (years) } & $18-30$ & 20 & 16,67 \\
\hline & & $31-43$ & 54 & 45,00 \\
\hline & & $44-56$ & 31 & 25,83 \\
\hline & & $57-70$ & 15 & 12,50 \\
\hline & Total & & 120 & 100 \\
\hline \multirow{2}{*}{3} & \multirow{2}{*}{ Position } & Owner & 100 & 83,33 \\
\hline & & Manager & 20 & 16,67 \\
\hline Total & & & 120 & 100 \\
\hline
\end{tabular}

Source: Own study.

Table 2 explains more female respondents than male respondents, where female respondents were 54.17 percent, while male respondents were 45.83 percent. When viewed by age, most respondents aged 31-43 years by 45 percent, then aged 18-30 years by 16.67 percent, ages 44-56 years by 25.83 percent, and aged 57-70 years by 12.5 percent. Based on its position in sector SMEs, it can be seen that as many as 100 people with a percentage of 83.33 percent are business owners and as many as 20 people with a percentage of 16.67 percent are business managers. Testing the instrument's validity and reliability was carried out with the Pearson Correlation and Cronbach's Alpha Coefficient. The results of testing the instruments' validity and reliability for each variable are presented in Table 3. The results of testing the validity and reliability of the instruments in Table 3 show that all variables are valid because the correlation value is above 0.30 and reliable because the Cronbach's Alpha value is above 0.6 .

Table 3. Instrument Validity and Reliability Test Results

\begin{tabular}{llll}
\hline Variable & Item & r Correlation & Cronbach's Alpha $\alpha$ \\
\hline Entrepreneurial & $\mathrm{X} 1$ & 0.766 & 0.758 \\
\cline { 2 - 4 } orientation $(\mathrm{X})$ & $\mathrm{X} 2$ & 0.688 & \\
\cline { 2 - 4 } & $\mathrm{X} 3$ & 0.801 & \\
\cline { 2 - 4 } & $\mathrm{X} 4$ & 0.585 & \\
\cline { 2 - 4 } & $\mathrm{X} 5$ & 0.747 & \\
\hline Business & $\mathrm{Y} 1.1$ & 0.755 & 0.755 \\
Innovation & $\mathrm{Y} 1.2$ & 0.763 & \\
Strategy (Y1) & $\mathrm{Y} 1.3$ & 0.744 & \\
\cline { 2 - 4 } & $\mathrm{Y} 1.4$ & 0.785 & \\
\hline Business & $\mathrm{Y} 2.1$ & 0.872 & \\
Performance (Y2) & $\mathrm{Y} 2.2$ & 0.771 & \\
\cline { 2 - 4 } & $\mathrm{Y} 2.3$ & 0.868 & \\
\hline
\end{tabular}

Source: Own study. 
Furthermore, the descriptive analysis of the variables explain the perception respondents of the entrepreneurial orientation variables, business innovation strategies, and business performance obtained through questionnaires. The quantitative assessment uses the interval scale by integrating the average score according to the assessment category.

\subsection{Convergent Validity}

An outer model test is carried out to ensure that the research indicators are feasible to be used as their role in measuring the research variables, then to see whether a model is valid to be the basis of the research, at least there are three criteria must be met: (1) all loading indicators must be above 0.65 ; (2) composite reliability (CR) must be above 0.8 ; (3) average variance extracted (AVE) for each construct must exceed 0.5 .

Table 4. Model Size Results

\begin{tabular}{|c|c|c|c|c|}
\hline Construct & Indicator & $\begin{array}{l}\text { Outer } \\
\text { Loading }\end{array}$ & $\begin{array}{l}\text { Composite } \\
\text { Reliability }\end{array}$ & $\begin{array}{l}\text { Average Variance } \\
\text { Extracted (AVE) }\end{array}$ \\
\hline \multirow{5}{*}{$\begin{array}{l}\text { Entrepreneurial } \\
\text { orientation }\end{array}$} & $\mathrm{X} 1$ & 0.782 & \multirow{5}{*}{0.871} & \multirow{5}{*}{0.574} \\
\hline & X2 & 0.735 & & \\
\hline & X3 & 0.710 & & \\
\hline & X4 & 0.745 & & \\
\hline & $\mathrm{X} 5$ & 0.813 & & \\
\hline \multirow{4}{*}{$\begin{array}{l}\text { Business } \\
\text { Innovation } \\
\text { Strategy }\end{array}$} & Y1.1 & 0.808 & \multirow{4}{*}{0.855} & \multirow{4}{*}{0.595} \\
\hline & Y1.2 & 0.752 & & \\
\hline & Y1.3 & 0.763 & & \\
\hline & Y1.4 & 0.763 & & \\
\hline \multirow{3}{*}{$\begin{array}{l}\text { Business } \\
\text { Performance }\end{array}$} & Y2.1 & 0.849 & \multirow{3}{*}{0.893} & \multirow{3}{*}{0.735} \\
\hline & Y2.2 & 0.853 & & \\
\hline & $\mathrm{Y} 2,3$ & 0.870 & & \\
\hline
\end{tabular}

Source: Own study.

Table 4 shows that all outer loading indicators have values above 0.65 with a range between 0.710 to 0.870 , which means they are in the recommendation limit. The composite reliability (CR) value is in the range between 0.855 to 0.893 , all of which are above 0.8 , meaning all The construct formed has good consistency as a research model, the third is the Average Variance Extracted Value (AVE) where everything is above 0.5 , with a range from 0.574 to 0.735 so it can be concluded that the research model in this study has good validity.

\subsection{Discriminant Validity}

To evaluate discriminant validity, a research model is recommended to ensure that the square root of Average Variance Extracted ( $\sqrt{A V E}$ ) of a latent variable must be greater. 
Table 5. Square Root of AVE

\begin{tabular}{|c|c|c|}
\hline Construct & $\begin{array}{l}\text { Average Variance } \\
\text { Extracted (AVE) }\end{array}$ & $\begin{array}{l}\text { Square Root of } \\
\text { AVE }\end{array}$ \\
\hline Entrepreneurial orientation & 0.574 & 0.758 \\
\hline Business innovation strategy & 0.595 & 0.771 \\
\hline Business Performance & 0.735 & 0.857 \\
\hline
\end{tabular}

Source: Own study.

The research model proposed in this study can be considered good, where the smallest value of $\sqrt{ } \mathrm{AVE}$ is equal to 0.758 greater than the correlation value between the highest latent variables that is equal to 0.710 in Table 5.

\subsection{Inner Model Test}

Structural models focus on hypothesized relationships or paths between latent variables. The results of testing the inner model can be seen in Figure 1.

Figure 1. Structural Model

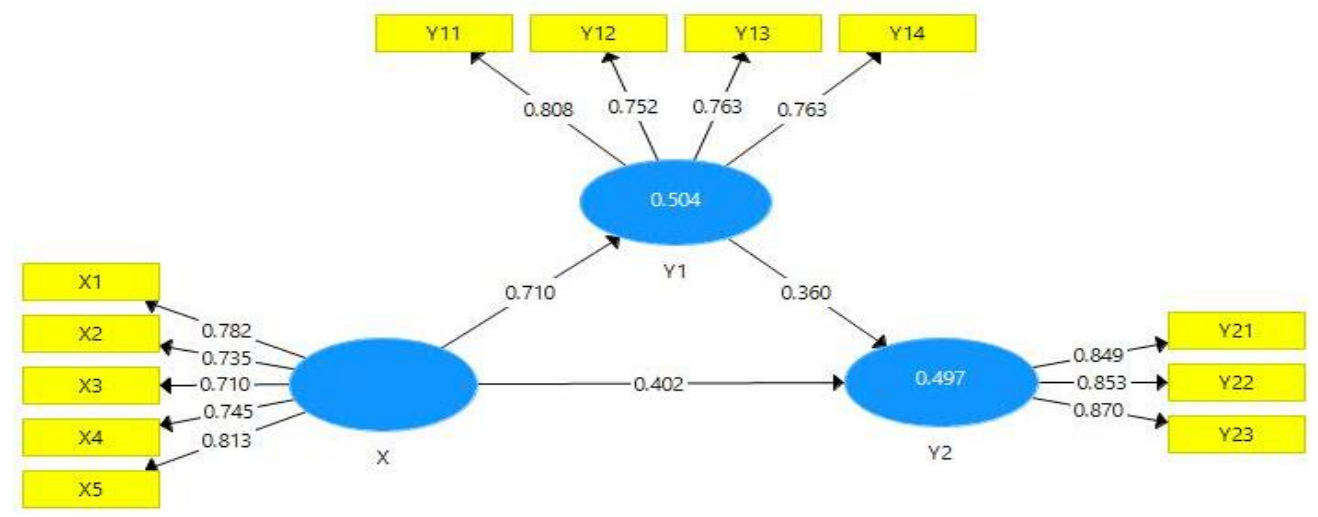

Source: Own study.

The structural model is evaluated using R-square for the dependent construct and ttest as well as the significance of the coefficient of structural path parameters.

\subsection{Hypothesis Testing}

Hypothesis test significance of the estimated parameters provides very useful information about the relationship between the research variables. The basis used in testing hypotheses is the value contained in the output path coefficients presented in Table 6. 
Table 6. Path Coefficients

\begin{tabular}{cclll}
\hline $\begin{array}{l}\text { Correlation between } \\
\text { Variables }\end{array}$ & coefficient & t-statistic & $\boldsymbol{P}$ Values & Information \\
\hline $\boldsymbol{E O}$-> BP & 0.402 & 3.950 & 0.000 & \\
$\boldsymbol{E} \boldsymbol{O}$-> BS & 0.710 & 13.138 & 0.000 & Accepted \\
BS $->$ BP & 0.360 & 3.372 & 0.001 & Accepted \\
\hline
\end{tabular}

Source: Own study.

Hypothesis testing is done by using t-statistics and looking at p-values. If the p-value $<0.05$, the hypothesis is accepted. Based on Table 6 , it can be explained that the entrepreneurial orientation towards business performance has a t-statistic value of 3.950 with a p-value of $0.000<0.05$, then the hypothesis is accepted. This means that the higher the level of entrepreneurial orientation, the higher the culinary sector SMEs' performance in the city of Denpasar. The entrepreneurial orientation towards the business innovation strategy has a t-statistic value of 13.138 with a p-value of $0.000<0.05$, so the hypothesis is accepted. This means that the higher the entrepreneurial orientation level of SMEs in Denpasar's clinical sector, the higher the business strategy for business innovation. Business strategy on business performance has a t-statistic value of 3.372 with a p-value of $0.001<0.05$, then the hypothesis is accepted. This means that the higher the business innovation strategy, the higher the culinary sector SMEs' performance in the city of Denpasar.

\subsection{Testing for Indirect Effects (Mediation Test)}

Test the role of business strategy mediation on the effect of entrepreneurial orientation on business performance by examining indirect effects, which are Smart PLS outputs, as presented in Table 7. Table 7 shows that the t-statistic value is greater than the t-table value $(3.354>1,96)$; the business innovation strategy significantly mediates entrepreneurial orientation towards business performance.

Table 7. Indirect Effects

\begin{tabular}{lllll}
\hline $\begin{array}{l}\text { Correlation } \\
\text { between Variables }\end{array}$ & $\begin{array}{l}\text { Path } \\
\text { coefficient }\end{array}$ & $\begin{array}{l}\boldsymbol{t} \text { - } \\
\text { Statistic }\end{array}$ & $\begin{array}{l}\boldsymbol{p} \text { - } \\
\text { Values }\end{array}$ & Information \\
\hline $\begin{array}{l}E O(\mathrm{X}) \rightarrow \mathrm{BS}(\mathrm{Y} 1) \\
\rightarrow \mathrm{BP}(\mathrm{Y} 2)\end{array}$ & 0.256 & 3.354 & 0.001 & Accepted \\
\hline
\end{tabular}

Source: Own study.

\section{Discussion}

\subsection{The Effect of Entrepreneurial Orientation on Business Performance}

Based on the analysis of the effect of entrepreneurial orientation on business performance, the beta coefficient value of 0.402 means that entrepreneurial orientation variables have a positive and significant effect on business performance. So, the higher entrepreneurial orientation of culinary SMEs in the Denpasar Bali is 
shown by their habit of always being brave, always introducing new products, daring to bear business risks, being more proactive than competitors, and ready to compete, then the business performance is increasing. The results of this study also related by the research of Pratono and Mahmood (2015), Gupta and Gupta (2015), Orlando et al. (2018), Mahrous and Genedy (2018), Babak et al. (2019), Tseng and Tseng (2019), which stated that entrepreneurial orientation had a positive and significant effect on business performance. This result is confirmed by the research of AlvarezTorres et al. (2019)

\subsection{The Effect of Entrepreneurial Orientation on Business Strategy}

Based on the analysis of the effect of entrepreneurial orientation on the implementation of business strategies, beta coefficient values of 0.710 were obtained with a significance level of $0.000 \leq 0.05$; these results mean, entrepreneurial orientation variables have a positive and significant effect on business innovation strategies. This means that the increasing entrepreneurial orientation of the culinary SMEs will increase business innovation strategies such as carrying out various innovations in its business, such as product innovation, service innovation, promotional innovation, and distribution innovation. The results of this study also related with the results of previous studies conducted by Tran et al. (2014), Manal et al. (2017), which states that entrepreneurial orientation had an important role in improving the implementation of business strategies in the form of various innovations that are carried out.

\subsection{Effect of Business Strategy on Business Performance}

Based on the analysis of the influence of business strategies on the business performance obtained a Beta coefficient of 0.360 with a significance level of $0.001 \leq$ 0.05), these results mean that business strategy positively and significantly affects business performance. This means that the higher the culinary sector SMEs in the city of Denpasar implement business strategies (business innovation), then improve business performance. The results of this study also related by the research of Dörner et al. (2011) about service innovation able to strengthen company performance, Yasa et al. (2016), Yuasa et al. (2020), and Setini et al. (2020) about an innovation strategy capable of enhancing the performance of SMEs. Anwar and Hasnu (2016) found that implementing the right business strategy had a positive effect on business performance. This result is also supported by Hutahayan's research (2019), his research results state that business strategy positively and significantly affects business performance.

\subsection{The Role of Business Strategy Mediates the Effect of Entrepreneurial Orientation on Business Performance}


Implementing business strategies by carrying out various innovations in business has been proven to have a positive and significant impact on business performance. Likewise, entrepreneurial orientation has a positive and significant impact on business performance. Based on testing the hypothesis on the role of implementing business strategies mediating the effect of entrepreneurial orientation on business performance is accepted with a total influence value of 0.256 . This study's results are in line with research conducted by Hutahayan (2019), who discovered the role of business strategy, namely business innovation mediating the effect of entrepreneurial orientation on business performance, and the business strategy significantly mediates entrepreneurial orientation towards business performance.

\section{Conclusions and Suggestions}

The business innovation strategy significantly mediates entrepreneurial orientation towards business performance. The mediation that occurs in this research model is partial. It can be said that the business innovation strategy variable serves to bridge the effect of entrepreneurial orientation on business performance. However, because of partial mediation, then without a business innovation strategy, entrepreneurial orientation can still have a positive and significant effect on business performance. This result means that if a culture of entrepreneurial orientation is increasingly high, it will strengthen the implementation of business innovation strategies, which in turn increases business performance achievement.

It is important for culinary sector SMEs in Denpasar to develop further ways of distributing their products better so that customers receive products that are faster and can satisfy customers; for example, during the Covid-19 pandemic, the SMEs sector could collaborate with Gojek, Grab and other distribution services.

The next researcher is expected to develop this research by later referring to the limitations of the research that has been previously presented and input of other factors that are felt to have mediated the effect of entrepreneurial orientation on business performance. These factors must be adjusted to the dynamics and trends in the digital era, such as digital business strategies, prospector strategies, social media promotion strategies, and hybrid strategies.

\section{References:}

Alvarez-Torres Francisco Javier, Gabriela Citlalli Lopez-Torres, Giovanni Schiuma. 2019. Linking entrepreneurial orientation to SMEs' performance: Implications for entrepreneurship universities, Management Decision, https://doi.org/10.1108/MD-112018-1234.

Anderson, B.S., Kreiser, P.M., Kuratko, D.F., Hornsby, J.S., Eshima, Y. 2015. Reconceptualizing entrepreneurial orientation. Strategic Management Journal, 36(10), 1579-1596.

Anwar, J., Hasnu, S. 2016. Business strategy and firm performance: a multi-industry analysis. Journal of Strategy and Management, 9(3), 361-382. 
Arshad, A.S., Rasli, A., Arshad, A.A., Zain, Z.M. 2014. The impact of entrepreneurial orientation on business performance: a study of technology-based SMEs in Malaysia. Procedia - Social and Behavioral Sciences in 4th International Conference on Marketing and Retailing, 130, Elsevier, Kuala Lumpur, 46-53.

Babak Taheri, Umit Bititci, Martin Joseph Gannon, Renzo Cordina. 2019. Investigating the influence of performance measurement on learning, entrepreneurial orientation, and performance in turbulent markets, International Journal of Contemporary Hospitality Management, https://doi.org/10.1108/ IJCHM-11-2017-0744.

Bahadir, S.C., Bharadwaj, S.G., Srivastava, R.K. 2015. Marketing mix and brand sales in global markets: examining the contingent role of country-market characteristics. Journal of International Business Studies, 46(5), 596-619.

Corallo, A., Errico, F., Latino, M.E., Menegoli, M. 2018. Dynamic business models: a proposed framework to overcome the death valley. Journal of the Knowledge Economy.

Gupta, V.K., Gupta, A. 2015. Relationship between entrepreneurial orientation and firm performance in large organizations over time. Journal of International Entrepreneurship, 13 (1), 7-27.

Hutahayan, B. 2019. Factors affecting the performance of Indonesian special food SMEs in entrepreneurial orientation in East Java. Asia Pacific Journal of Innovation and Entrepreneurship, DOI 10.1108/APJIE-09-2018-0053.

Lechner, C., Gudmundsson, S.V. 2014. Entrepreneurial orientation, firm strategy and small firm performance. International Small Business Journal, 32(1), 36-60, available at http://doi.org/10.1177/0266242612455034.

Mahrous, A.A., Genedy, A.M. 2018. Connecting the dots: The relationship among Intra organizational environment, entrepreneurial orientation, market orientation, and organizational performance. Journal of Entrepreneurship in Emerging Economies, https://doi.org/10.1108/ JEEE-09-2016-0036.

Manal Yunis Abdul-Nasser El-Kassar Abbas Tarhini. 2017. Impact of ICT-based Innovations on Organizational Performance: The Role of Corporate Entrepreneurship. Journal of Enterprise Information Management, 30(1). http://dx.doi.org/10.1108/JEIM-01-2016-0040.

Meyer, K.E., Su, Y.S. 2015. Integration and responsiveness in subsidiaries in emerging economies. Journal of World Business, 50(1), 149-158.

Orlando Rua, Alexandra França, Rubén Fernández Ortiz. 2018. Key drivers of SMEs export performance: the mediating effect of competitive advantage. Journal of Knowledge Management, https://doi.org/10.1108/JKM-07-2017-0267.

Pratono, A.H., Mahmood, R. 2015. Entrepreneurial orientation and firm performance: how can micro, small, and medium-sized enterprises survive environmental turbulence? Pacific Science Review B: Humanities and Social Sciences, 1(2), 85-91.

Putra, I., Sunarsih, N., Novitasari, L., Setini, M. 2020. Exploring the relationship between social capital, innovation capability and innovation during the coronavirus pandemic. Uncertain Supply Chain Management, 8(4), 857-864.

Schepers, J., Voordeckers, W., Steijvers, T., Laveren, E. 2014. The entrepreneurial orientation- performance relationship in private family firms: the moderating role of socioemotional wealth. Small Business Economics, 43(1), 39-55.

Setini, M., Yasa, N.N.K., Gede Supartha, I.W., Ketut Giantari, I., Rajiani, I. 2020. The Passway of Women Entrepreneurship: Starting from Social Capital with Open Innovation, through to Knowledge Sharing and Innovative Performance. Journal of Open Innovation: Technology, Market, and Complexity, 6(2), 25. 
Thoumrungroje, A., Racela, O. 2013. The contingent role of customer orientation and entrepreneurial orientation on product innovation and performance. Journal of Strategic Marketing, Vol. 21, No. 2, 140-159, DOI: 10.1080/0965254X.2012.742129.

Tran, Q., Zhang, C., Sun, H., Huang, D. 2014. Initial adoption versus institutionalization of e-procurement in construction firms: An empirical investigation in Vietnam. Journal of Global Information Technology Management, Vol. 17, No. 2, 91-116.

Tseng, C., Tseng, C.C. 2019. Corporate entrepreneurship as a strategic approach for internal innovation performance. Asia Pacific Journal of Innovation and Entrepreneurship, 13(1), 108-120.

Yasa, N.N.K., Sukaatmadja, I.P.G., Giantari, I.G.A.K., Rahyuda, H. 2016. The role of innovation strategy in mediating the influence of company resources on woodcraft industry performance in Gianyar regency. International Business Management.

Yasa, N.N.K., Yasa, N.N.K., Giantari, I.G.A.K., Giantari, I.G.A.K. 2020. The role of competitive advantage in mediating the effect of promotional strategy on marketing performance. Management Science Letters, 10(12). 